\title{
Tao Yuanming's Perspectives on Life as Reflected in His Poems on History
}

\author{
Zhang Yue 張月 \\ Associate Professor of Department of Chinese Language and Literature, \\ University of Macau, Taipa, Macau, China \\ bnuzhangyue@gmail.com
}

\begin{abstract}
Studies on Tao Yuanming have often focused on his personality, reclusive life, and pastoral poetry. However, Tao's extant oeuvre includes a large number of poems on history. This article aims to complement current scholarship by exploring his viewpoints on life through a close reading of his poems on history. His poems on history are a key to Tao's perspectives with regard to the factors that decide a successful political career, the best way to cope with difficulties and frustrations, and the situations in which literati should withdraw from public life. Examining his positions reveals the connections between these different aspects. These poems express Tao's perspectives on life, as informed by his historical predecessors and philosophical beliefs, and as developed through his own life experience and efforts at poetic composition.
\end{abstract}

\section{Keywords}

Tao Yuanming - poems on history - perspectives on life

Tao Yuanming 陶淵明 [ca. 365-427], a native of Xunyang 潯陽 (contemporary Jiujiang 九江, Jiangxi), is one of the best-known and most-studied Chinese poets from before the Tang [618-907]. His extant corpus, comprising 125 poems and 12 prose works, is one of the few complete collections to survive from early medieval China, largely thanks to Xiao Tong 蕭統 [501-531], a prince of the Liang dynasty [502-557], who collected Tao's works, wrote a preface, and 
composed one of his extant biographies. ${ }^{1}$ Over the years, Tao's pastoral poetry, his biography, and his reclusive lifestyle have received much attention from scholars using both traditional text-centered approaches and new approaches informed by manuscript culture, reception studies, and research into reading practices. ${ }^{2}$ Scholars have examined the factors which impacted Tao's personality, lifestyle, and stylistic choices, focusing on the influence of "dark learning" or Neo-Daoism [xuanxue 玄學] on Tao's perspective on life [rensheng guan 人生觀] and his writing. ${ }^{3}$ This article complements the current research direction and investigates Tao's rensheng guan as reflected and established in his poems on history [yongshi shi 詠史詩]. These poems constitute roughly one fourth of Tao's extant oeuvre, to the point that more of Tao's yongshi shi survive than those of any other early medieval Chinese poet. ${ }^{4}$

* Zhang Yue has been a Research Fellow in the Institute of Advanced Studies in Humanities and Social Sciences at the University of Macau since August 2020. This article is sponsored by The Chinese National Key Program in Humanities and Social Sciences 國家社科基金重 大項目: Tao Yuanming Source Integration and Research 陶淵明文獻集成與研究 (Project No.: 17ZDA252) and University of Macau's Start-up Research Grant (SRG2O19-0o197-FAH). I am grateful to Fan Ziye 范子燁, Zhong Shulin 鍾書林, Dylan Suher, the journal editor Benjamin Hammer, and the anonymous reviewer who provided their useful comments and suggestions.

1 Before the Tang dynasty, four biographies were compiled and written on Tao's life, including Xiao Tong's The Collection of Tao Yuanming's Writings [Tao Yuanming ji 陶淵明集], and three standard histories: The History of the Song Dynasty [Songshu 宋書], The History of Jin Dynasty [Jinshu 晉書], and The History of the Southern Dynasties [Nanshi 南史].

2 For the discussion and review of the recent English scholarship on Tao Yuanming studies, see Zhang Yue 張月, "Ou Mei jinqi Tao Yuanming yanjiu zongshu fenxi yu zhanwang 歐美近期陶淵明研究綜述、分析與展望," Gudian wenxian yanjiu 古典文獻研究 20.2 (2017): 289-304. For the recent Chinese books on Tao Yuanming, see Yue Zhang, "A Selective Bibliography of Mainland Chinese Books (2010-2019) on Early Medieval Chinese Literature," Early Medieval China 26 (2020): 99-100 and Yue Zhang, "A Selective Bibliography of Mainland Chinese Books (2002-2010) on Early Medieval Chinese Literature (220-589)," Early Medieval China 18 (2012): $77-78$.

3 For the recent studies on Xuanxue, see David Chai, ed., Dao Companion to Xuanxue 玄學 (Neo-Daoism) (Dordrecht: Springer, 2020). For the relationship between Xuanxue and Tao Yuanming's perspective on life, see Luo Zongqiang 羅宗強, Xuanxue yu Wei Jin shiren xintai 玄學與魏晉士人心態 (Hangzhou: Zhejiang renmin chubanshe, 1991), 342-358; Tao Xinmin 陶新民, “Tao Yuanming: Xuanxue rensheng guan de zhongjie yu xuanyan shi de chaoyue 陶淵明：玄學人生觀的終結與玄言詩的超越, Anhui daxue xuebao 安徽大學 學報, 24.1 (2000): 40-46; Li Yaonan 李耀南, “Xuanxue shiye zhong de Tao Yuanming rensheng guan he shenmei rensheng jingjie 玄學視野中的陶淵明人生觀和審美人生境界,” Huazhong keji daxue xuebao 華中科技大學學報, no. 6 (2002): 23-28.

4 Wei Chunxi 韋春喜 lists 25yongshi shi attributed to Tao. See, Wei Chunxi 韋春喜, Song qian yongshi shi shi 宋前詠史詩史 (Beijing: Zhongguo shehui kexue chubanshe, 2010), 94. 
Through writing yongshi shi, Tao synthesized relevant historical materials with his own perception of various aspects of life, including but not limited to his views of political careers, poetry composition, the experience of reclusion, and family life. Tao developed his rensheng guan by discussing three main issues in his yongshi shi: the desire for the proper appreciation of scholars, the problem of following the Dao in poverty, and the idea of withdrawing from politics after achieving results. Tao's views on these issues hinge on his understanding of “timeliness" [shi 時]. Although Tao was not the first writer to discuss these problems, his innovation was to connect these different issues and to internalize and individualize principles drawn from the lives of the ancients, which he applied not only to his poetry but also to his life. This innovation of practicing the values that he discussed in his yongshi shi in turn heightened the significance of these ancient figures.

Tao Yuanming read widely in history, so he could interpret ancient figures from a variety of perspectives. Scholars have widely acknowledged that Tao was exceptionally well read in history. Qi Yishou 齊益壽 believes that Tao Yuanming's erudition likely stems from the influence and environment of his family, which possessed large private collections of books. Tao Yuanming was described by Yan Yanzhi 顏延之 [384-456] as someone "fond of rare books" [xinhao yishu 心好異書]. According to Qi Yishou's analysis of the ancient books cited in Tao's yongshi shi, he had read Records of the Grand Historian [Shiji 史記], The History of the Han Dynasty [Hanshu 漢書], Continuation of the History of the Han Dynasty [Xu Hanshu 續漢書], Records of the Later Han Dynasty [Hou Hanji 後漢記], Records of the Jin Dynasty [Jin ji 晉紀], Records of the State of $W u[W u$ lu 吳錄], The Definite Record of the Three Adjuncts [Sanfu juelu 三輔決錄], and Biographies of the Former Worthies of Runan [Runan xianxian zhuan 汝南先賢傳]. ${ }^{5}$ Zhong Shulin 鍾書林 believes that Tao's mastery of history [shicai 史才] accounts for his appointment as the editorial director of the Palace Library [Zhuzuo lang 著作郎], though Tao refused to accept the nomination. ${ }^{6}$ Tao's works demonstrate a consistent respect for the craft of history. In the History of Northern Dynasties [Beishi 北史], Shen Yue 沈約 [441-513] states that Tao's contemporaries regarded "The Biography of Mr. Five Willows" [Wuliu xiansheng zhuan 五柳先生傳] as an "authentic record" [shilu 實錄]. ${ }^{7}$ Tao's "Biography of the Former Chief of Staff to the Jin Generalissimo

5 Qi Yishou 齊益壽, Huangju dongli yao gujin: Tao Yuanming qiren qishi sanlun 黃菊東篗耀 古今：陶淵明其人其詩散論 (Taipei: Guoli Taiwan daxue chubanshe, 2016), 7 .

6 Zhong Shulin 鍾書林, Yinshi de shendu 隱士的深度 (Beijing: Zhongguo shehui kexue chubanshe, 2015), 337-339.

7 Shen Yue 沈約, Songshu 宋書 (Beijing: Zhonghua shuju, 1974), 93.2287. 
for Subduing the West His Excellency Meng” [Jin gu Zhengxi dajiangjun Zhangshi Meng fujun zhuan 晉故征西大將軍長史孟府君傳] was added to the official biography of Meng Jia 孟嘉 [ca. mid-fourth century]. ${ }^{8}$ Moreover, Tao's other works, such as "Nine Poems after Reading the Shiji" [Du Shi shu jiuzhang 讀史述九章] and “In Praise of the Paintings on a Fan" [Shanshang huazan 扇上畫贊], demonstrate his historical acumen. For example, although the concluding remarks sometimes differ from those in the standard histories in terms of their perspective and content, Du Shi shu jiuzhang continues the historiographical tradition of the Shiji and Hanshu by commenting on historical figures at the end of each biography. Later compilers of official histories considered Tao's writings of high historical value. As part of his engagement with history, Tao wrote many yongshi shi.

Most of the historical figures about whom Tao wrote were talented scholars who suffered political setbacks and were therefore unable to realize their ideals in the societies in which they lived. As for the difficulties they faced in accomplishing their political goals, Tao argues that, given the fickleness of public opinion, timeliness plays a key role in determining one's success. ${ }^{9}$ For Tao, timeliness refers to both conditions that one can control - speaking or writing the right message with the right delivery at the right moment - and conditions beyond one's control, such as whether one was born in a harmonious society and has the opportunity to serve a virtuous ruler. In the following poem on Qu Yuan 屈原 [са. 340-278 вCE] and Jia Yi 賈誼 [200-168 вС ], Tao emphasizes the role of timeliness in the careers of the two scholars:

$\begin{array}{ll}\text { 屈賈 } & \text { Qu Yuan and Jia } \mathrm{Yi}^{10} \\ \text { 進德修業, } & \text { By advancing virtues and refining achievements, } \\ \text { 將以及時。 } & \text { One will act in a timely manner. }{ }^{11}\end{array}$

8 I adopt the English translation of the title from A. R. Davis, T'ao Yüan-ming ( $A D{ }_{365-427):}$ His Works and Their Meaning (Cambridge: Cambridge University Press, 2009), 1: xii.

9 Yuan Xingpei 袁行需, Tao Yuanming ji jianzhu 陶淵明集箋注 (Beijing: Zhonghua shuju, 2003), 432.

10 Yuan, Tao Yuanming ji jianzhu, 520. Qu Yuan was a legendary scholar-official in the state of Chu during the Warring States period $\left[475^{-221}\right.$ вCE $]$. He was slandered and exiled to the south, where he eventually committed suicide by drowning in the Miluo River 泪羅 江. Jia Yi was a scholar official in the Western Han dynasty [2O2 BCE-25 CE]. He sought to institute reforms and reduce the power of local lords, but he was slandered by officials opposed to him and died young at the age of 33 .

11 The first couplet also appears in the biography that Tao wrote for Meng Jia, Tao's maternal grandfather. 


$\begin{array}{ll}\text { 如彼稷契, } & \text { Such was the case with Ji and Xie, }{ }^{12} \\ \text { 孰不願之? } & \text { Who would not wish to be like them? } \\ \text { 嗟乎二賢, } & \text { Alas! The two virtuous scholars, }{ }^{13} \\ \text { 逢世多疑。 } & \text { They encountered a distrustful world. } \\ \text { 候詹寫志, } & \text { Visiting Zhanyin, Qu wrote down his intentions, }{ }^{14} \\ \text { 感朋獻辭。 } & \text { Shaken by the arrival of the owl, Jia Yi presented } \\ & \text { his rhetoric. }{ }^{15}\end{array}$

The four-character lines of this short poem resemble the commentary historians traditionally placed at the end of biographies in standard histories. Tao's preface to this series of poems states, "I was moved by reading the Shiji and wrote poems to express my feelings." ${ }^{16}$ Qu Yuan and Jia Yi were discussed together in one biography in Sima Qian's 司馬遷 [145-90 BCE] Shiji, which likely influenced Tao's choice to pair them together in this poem.

At the beginning of this poem, Tao seems to espouse a conventional Confucian teaching: that timeliness is essential to cultivating one's moral values and advancing one's career. He cites Ji 稷 and Xie 契 as examples of men who encountered a time when their abilities were appreciated by virtuous rulers and put in a good use. By way of contrast, Qu Yuan and Jia Yi were virtuous and willing to serve, but they had the misfortune of not being born at the right time and not encountering worthy rulers. Despite having abilities comparable to the exemplary officials Ji and Xie, Qu and Jia were doubted, slandered, and forced into exile. Consequently, their potential was never fully realized, and they were instead forced to use literature to articulate their thoughts and vent their frustrations with respect to society and politics. Tao wrote this poem after reading the Shiji, which suggests that Tao's understanding of the function of literature commenting on social reality is inspired by Sima Qian's theory of "venting frustrations" [ fafen 發憤] from "The Letter to

$12 \mathrm{Ji}$ and Xie were virtuous and capable officials during the reign of the mythical emperor Shun 舜. See, Sima Qian 司馬遷, Shiji 史記 (Beijing: Zhonghua Shuju, 1959), 1.38.

13 "The two virtuous scholars" refers to Qu Yuan and Jia Yi.

14 This line refers to an episode where Qu Yuan asked Zheng Zhanyin 鄭詹尹 [ca. 4th3rd century в $\mathrm{CE}$ ] to perform a divination to resolve his questions and doubts. The poem "Divination on Dwelling” [Buju 卜居], traditionally attributed to Qu Yuan, expresses his ambitions.

15 This line refers to an incident in which Jia Yi saw an owl entering his house, an omen of a shortened life span. In lamentation, he composed "Rhapsody on an Owl" [Funiao fu 胒鳥賦].

16 Yuan, Tao Yuanming ji jianzhu, 512. In a series of thirteen poems on "Reading The Classic of Mountains and Seas" [Du Shanhai jing 讀山海經], Tao is also very explicit about his reading practices. 
Ren'an" [Bao Ren'an shu 報任安書]. ${ }^{17}$ In that letter, Sima proposes that masterpieces are produced through this impulse of fafen, and he tapped into that impulse to compose the Shiji. In expressing sentiments similar to Sima's, Tao may have been signaling his desire to use his writings to transmit his reputation to future readers and compensate for his political frustrations. This poem shows that Tao believed that opportune timing was essential for cultivating moral values and advancing one's career; otherwise, the difficulties and frustrations would be insurmountable. In this difficult situation, what is Tao's perspective on scholars' choice and development? Should they continue expending effort to become politically successful? In a poem on Han Fei 韓非 [280-233 BCE], provided below, Tao insists that no matter how ingenious and assiduous a scholar is, if the time is not right, they will fail in their endeavors, or even undermine their goals:
韓非
Han Fei ${ }^{18}$
豐狐隱穴,
The sleek-furred fox conceals himself in a den,
以文自殘。
because of his patterning, he brings calamity on himself. ${ }^{19}$
君子失時,
If a gentleman loses his moment,
白首抱關。
he will still be a gatekeeper even when his hair is white.
巧行居災,
Clever actions harbor disaster;
忮辯召患。
Shrewd arguments invite worry.
哀矣韓生,
How sorrowful Master Han was!
竟死說難。
Unexpectedly, he died from "The Difficulties
of Persuasion." ${ }^{20}$

17 Ban Gu 班固, Hanshu 漢書 (Beijing: Zhonghua shuju, 1962), 62.2423.

18 Yuan, Tao Yuanming ji jianzhu, 523 .

19 This couplet alludes to a passage in the Zhuangzi: "The sleek-furred fox and the elegantly spotted leopard dwell in the mountain forest and crouch in the cliffside caves - such is their quietude. They go abroad by night but lurk at home by day - such is their caution. Though hunger, thirst, and hardship press them, they steal forth only one by one to seek food by the rivers and lakes - such is their forethought. And yet they can't seem to escape the disaster of nets and traps. Where is the blame? Their fur is their undoing." The English translation follows the one provided by Burton Watson, The Complete Works of Zhuangzi (New York: Columbia University Press, 2013), 157. The original Chinese is from Wang Xianqian 王先謙, Zhuangzi jijie 莊子集解 (Beijing: Zhonghua shuju, 1987), 20.168. My translation of Tao's couplet borrows from Burton's translation of the Zhuangzi passage. For a detailed discussion of Han's "Shuinan," see Sima Qian, Shiji, 63.2147-2148, and Michael Hunter, “The Difficulty with “The Difficulties of Persuasion' ('Shuinan' 說難),” in Dao Companion to the Philosophy of Han Fei, ed. P. R. Goldin (New York: Springer, 2013), 169-195. For the English translation of Han Fei's works, see Burton Watson, trans., Han Fei Tzu: Basic Writings (New York: Columbia University Press, 1964). 
The paradox at the heart of this poem demonstrates that the pursuit of political success, social status, and even a fulfilling life can lead to ruin in the end. In Han Fei's case, his cleverness and eloquence led directly to a tragic fate. Han Fei was a statesman during the Warring States period [475-221 BCE], who moved to the state of Qin [770-2O7 BCE] when the King of Han [4O3-23О BCE] did not adopt his recommendations. Han was initially favored by the Qin king, but when he opposed Li Si's 李斯 [ca. 284-208 BCE] plan to annex the other six states, Li slandered Han in front of the king, which led to Han Fei's imprisonment and poisoning. ${ }^{21}$ In the end, Han's talent led to his own demise. In his work "Shuinan" 說難, Han discussed methods for persuading rulers, but failed to persuade the ruler of Qin of his own worth, and was persecuted for irritating a major official. Tao therefore uses Han's life experience to express his perspective on losing one's moment. If someone misses their moment, regardless of their effort and dedication, they cannot achieve anything, and in fact, ironically, the more effort they put in, the quicker and more dramatic their failure will be. Yet at the same time that Tao believes that timeliness is indispensable, he also believes that compromising one's principles, whatever the circumstances might be, is never acceptable. This principle is made clear in Tao's poem on the two recluses of $\mathrm{Lu}$, a reworking of a story from the Shiji:

魯二儒
易代隨時, “The Two confucian Scholars from the State of $\mathrm{Lu}^{22}$
迷變則愚。 If puzzled by changes, one is truly confounded."
介介若人,
特為貞夫。 Thright gentlemen the two Confucian scholars were,
德不百年, “When virtue has not been present for a hundred years,
汗我詩書。 It taints our documents."
逝然不顧, They resolutely ignored [Shusun's invitation],
被褐幽居。 Wearing coarse clothes, they lived in reclusion.

The first couplet initially seems to be Tao's own commentary but is actually a subtle citation of an observation by Shusun Tong 叔孫通 [d. ca. 188 вCE] in the biographies of the Western Han [206 BCE-25] officials Liu Jing 劉敬 [fl. 200 BCE] and Shusun Tong in the Shiji. The couplet quotes Shusun's opinion

21 For Han Fei's story, see Sima Qian, Shiji, 63.2146-2148.

22 Yuan, Tao Yuanming jijianzhu, 525.

23 There is a variant version of this line, where 代 is replaced by 大. If we choose the variant, the line reads "changes largely follow the times." This variant reading shows even clearer evidence of the importance of historical moment to Tao. See Yuan, Tao Yuanming ji jian$z h u, 525$. 
that two Confucian scholars who refused to participate in the reformation of rites and procedures for the new Han dynasty held antiquated beliefs. ${ }^{24}$ However, the second couplet shows that Tao does not consider these scholars to be backward; instead, Tao praises the two scholars for their integrity, overlooking their seemingly eccentric behavior, because the two Confucian scholars spurned Shusun, stating, "He served almost ten rulers, and he obtained each one's favor through obsequiousness." ${ }^{25}$ With respect to Shusun Tong, Tao's opinion diverges from that of Sima Qian, who praised Shusun: "Shusun Tong observed the world and adjusted his approach to affairs, establishing and adapting rituals in accordance with the changing times. Eventually, he became the Confucian elder master of the Han dynastic house."26 Tao, however, advocates holding steadfast to one's principles, regardless of the changing times. He emphasizes the virtuous words and deeds of the two scholars. For instance, the third couplet changes to the first person, mimicking the two scholars' tone as they refused to help reform ritual and music for the new dynasty, since they believed that such a reformation should only be conducted after a long period of ascending virtue. Tao revered the way in which the two scholars from Lu maintained their integrity. In other poems dealing with personal choice in a fast-changing transitional environment, Tao advocated for withdrawing from public life and "delighting in the Dao in poverty" [anpin ledao 安貧樂道] instead of changing with the times.

As discussed above, timeliness is a key prerequisite for the exercise of virtue. If the moment is right, a virtuous scholar should serve the state, but if the moment is not right, those who do not want to sacrifice principles should, according to Tao, anpin ledao. Tao not only advocated this principle in his writing, but also tried to practice this ideal in his own life, despite knowing the difficulty and drudgery that this lifestyle would entail. As he wrote in his "Stirred by Unappreciated Scholars" [Gan shi buyu fu 感士不遇賦], "I would rather suffer poverty to achieve my intentions, / neither compromising nor burdening myself." ${ }^{27}$ Tao motivated himself to delight in poverty and enjoy a life suited to his nature by reflecting on figures from history who followed a similar path. In a poem composed in 4O3, Tao praises the concept of anpin ledao and demonstrates how he applied it to his own life.

\footnotetext{
24 Sima Qian, Shiji, 99.2722-2723.

25 Sima Qian, Shiji, 99.2722.

26 Sima Qian, Shiji, 99.2726.

27 Yuan, Tao Yuanming jijianzhu, 433.
} 


$\begin{array}{ll}\text { 癸卯歲始春懷古田舍 其二 } & \begin{array}{l}\text { Meditating on the Past in a Farmhouse } \\ \text { at the Beginning of Spring in the }\end{array} \\ & \begin{array}{l}\text { Guimao Year II }{ }^{28} \\ \text { The Old Teacher left us the lesson, }\end{array} \\ \text { 先師有遺訓, } & \text { "Worry about the Dao, not } \\ \text { 憂道不憂貧。 } & \begin{array}{l}\text { about poverty"29 } \\ \text { I see this lesson from afar, too dis- } \\ \text { tant to grasp. }\end{array} \\ \text { 瞻望邀難逮, } & \begin{array}{l}\text { I make my desire and aim to be upright } \\ \text { and diligent. }\end{array} \\ \text { 轉欲志長勤。 } & \begin{array}{l}\text { Grasping a plow, I take joy in seasonal } \\ \text { farm work. }\end{array} \\ \text { 秉来歡時務, } & \text { Letting out a smile, I encourage } \\ & \text { the farmers. } \\ \text { 解顏勸農人。 } & \text { The level farmland meets distant winds, } \\ \text { 平疇交遠風, } & \text { Good sprouts embrace new things. } \\ \text { 良苗亦懷新。 } & \end{array}$

The "Old Teacher" Tao refers to is Confucius, a substantial influence on Tao's writings and thought, whose injunction from the Analects he quotes: "Worry about the Dao, not about poverty!" Given a hypothetical extreme situation, Confucius advocates that a gentleman should seek and follow the Dao no matter what poverty or misfortune he encounters:

The Master said, "The gentleman devotes his mind to attaining the Dao and not to securing food. Go and till the land and you will end up by being hungry, as a matter of course; study, and you will end up with the salary of an official, as a matter of course. The gentleman worries about the Dao, not about poverty." ${ }^{\prime 30}$

Here Confucius emphasizes the importance of the Dao, which is achieved through cultivating virtues and moral values, over material needs like food. Discussing Tao's allusion to the Analects, James Hightower suggests that Tao understood Confucius as believing that study was a reliable key to the Dao. Because his impoverishment was an obstacle to study, Tao farmed for a

28 Yuan, Tao Yuanming ji jianzhu, 867. This poem was written in the second year of the Yuanxing 元興 reign [4O2-404] when Tao was 52 years old.

29 This line is a direct quote from the Analects.

30 D.C. Lau, Confucius: The Analects (New York: The Penguin Group, 1979), 136. I have substituted "Dao" for "Way." 
living, providing a physical and financial foundation for studying the classics. Eventually, Tao's personal way of dealing with difficult situations shaped his perspective on ancient figures, which in return contributed to his decision to live a reclusive life and his firm belief in anpin ledao. Alan Berkowitz has noted that "recluses" in early medieval China were actually highly sociable and "reclusion" often served as a short-cut for seeking remunerative official positions. ${ }^{31}$ By way of contrast, Tao advocated for a sincere reclusion aimed at adhering to the Dao. His position was expressed through a series of seven poems on ancient scholars who were materially poor but spiritually rich. ${ }^{32}$ In each of these poems, he starts with the theme of the brutality of the natural world - a severe winter or gloomy weather - then discusses the effects of the poverty that the scholars suffered, such as a lack of proper food and clothes, before finally posing a rhetorical question to show that despite this unfavorable situation, these poor scholars cited ancient figures as role models, and ultimately found contentment by delighting in the Dao. Three poems from Tao's series of “Poems on Impoverished Scholars" [Yong pinshi 詠貧士] explore Tao's belief of anpin ledao. In the second poem of this series, we get a glimpse of Tao's life:

\begin{tabular}{|c|c|}
\hline 其二 & $\mathrm{II}^{33}$ \\
\hline 庽 & nd of the year, \\
\hline 首軾工 & $\begin{array}{l}\text { Wearing coarse clothes, I was sunbathing at my } \\
\text { front window. }\end{array}$ \\
\hline 貴秀, & The southern field bore no grain. \\
\hline 七京 & Withered twigs filled the northern garden. \\
\hline & Pouring out the jug, not one drop was left. \\
\hline 見煙。 & Glancing at the stove, I saw no smoke. ${ }^{34}$ \\
\hline & Ancient writings were crammed around my seat. ${ }^{35}$ \\
\hline & At sunset, there is no \\
\hline
\end{tabular}

31 Alan Berkowitz, Patterns of Disengagement: The Practice and Portrayal of Reclusion in Early Medieval China (Stanford: Stanford University Press, 200o), 64.

32 Most modern scholars have dated this series of poems to Tao's later life, between 420 and 421, but Davis believes that this poem could have been written earlier, between 402 and 405. See Davis, T'ao Yüan-ming, 1.136.

33 Yuan, Tao Yuanming ji jianzhu, 366.

34 Tao described other difficulties he encountered in other poems. For example, his house was destroyed by a fire [Suffering a Fire in the Sixth Month of the Year Wuwu 戊午歲六月 中遇火] and he occasionally begged for food during famines [Begging for Food 乞食]. The English translation of these titles follows Davis's English translation.

35 I follow Yuan Xingpei's interpretation of 詩書 as meaning ancient writings in general. See Yuan, Tao Yuanming ji jianzhu, 368. 


$\begin{array}{ll}\text { 閑居非陳厄, } & \begin{array}{l}\text { Loafing at home is not encountering hardship } \\ \text { in Chen, }\end{array} \\ & { }^{36}\end{array}$

Tao seems to live in constant want of clothes, food, and wine. He dealt with these quotidian worries by reading books, including such Confucian classics as the Book of Songs [Shijing 詩經] and the Documents [Shangshu 尚書]. Reading books, enjoying music (in particular, playing the zither and singing), and engaging in conversation created cultural capital which compensated for the material deprivation of the lifestyle of the recluse. However, the extreme poverty Tao suffered made it difficult to engage in even these activities. As Robert Ashmore discusses, the central irony of the poem is "a tension between an ideal and a person who confronts that ideal and questions whether it is adequate to his experience or his experience adequate to it." ${ }^{37}$ Tao is surrounded by books and yet is unable to engage in the study that is indispensable to his literati identity and ideals of moral cultivation. The continuous use of strong negative words, such as "has/have no" [wu 無], "absolute/absolutely" [jue 絕], “no/not" [ $b u$ 不], and "no/not” [ $f e i$ 非], reveals Tao's helplessness and embarrassment, and engenders compassion within the reader. Tao's embarrassment is also revealed through self-effacing comic detail: "sunbathing" because he lacks clothes in winter, pouring out an empty jar. To mitigate the tension between ideal and reality and console himself, Tao looks to figures from history. Tao adopts the character $c i$ 此 in the last line to refer to the virtuous men of antiquity. This is not the only occasion that Tao weathered dire poverty by focusing on the example of ancient virtuous figures and their works. In the poem "Presented to My Cousin Jingyuan in the Twelfth Month of the Guimao Year” [Guimao sui shieryue zhong zuo yu congdiJingyuan 癸印歲十二月中作與 從弟敬遠], Tao describes a period spent in his poor and empty house surveying ancient books. Although the sages were gone, the writings that recorded their words and deeds remained. The books were Tao's companions as he actively sought to follow in the footsteps of the sages.

Tao's aim in following the example of the sages was to adhere to the Dao, even in a moment of great difficulty. The Dao in Tao's mind was not abstract,

$3^{6} \quad$ A reference to an episode in the life of Confucius in which he and his disciples were imperiled in the state of Chen.

37 Robert Ashmore, The Transport of Reading: Text and Understanding in the World of Tao Qian (Cambridge: Harvard University Asia Center, 2010), 220. 
but was instead realized by the virtuous lives his predecessors had led. He depended for spiritual support on the deeds and ideals of ancient worthies, who, although they encountered enormous constraints and difficulties, appeared calm, detached, and still focused on their ideals. A poem on Rong Qiqi 榮啓期 [571-474 BCE] and Yuan Xian 原憲 [b. 515 BCE] illustrates Tao's psychological dependence on models of anpin ledao:

\begin{tabular}{|c|c|}
\hline$E$ & $\mathrm{III}^{38}$ \\
\hline 舅老帶索, & pe as a belt, \\
\hline 方彈琴。 & [But] he delighted in playing the zither. \\
\hline 納决屨, & Scholar Yuan wore broken sandals, \\
\hline 昜商音。 & [But] he sang "The Hymns of Shang" clearly. 39 \\
\hline 戏久， & Chonghua left us long ago. ${ }^{40}$ \\
\hline 启。 & $\begin{array}{l}\text { Impoverished scholars have searched for each other } \\
\text { for generations. }\end{array}$ \\
\hline & His tattered garment could not cover his elbow. \\
\hline & His $g$ \\
\hline & How could he forget wearing soft fur? \\
\hline & Obtaining it improperly is not something to be admired. \\
\hline & ly good at sophistry. ${ }^{41}$ \\
\hline & Therefore, he could not understand my \\
\hline
\end{tabular}

In the first couplet, Tao praises Rong Qiqi, a character in the Liezi 列子 whose life and personality Confucius apparently admired. Although Rong lived in poverty, he was nevertheless happy. As Rong explains to Confucius:

My joys are very many. Heaven gives birth to the Ten Thousand Things, but man alone is noble. I had the luck to become a man; this is my first joy. In the distinction of male and female, the male is noble and the female

$38 \quad$ Yuan, Tao Yuanming ji jianzhu, 368.

39 The meaning of "Shang" here is somewhat unclear. It could mean the second note of the scale, which is often associated with melancholy and depression. Davis argues, "Since T'ao appears to follow written sources so closely here, it seems best to understand it as 'The Hymns of Shang' (from the Book of Songs), which Yuan Xian is described as singing." See Davis, T'ao Yüan - ming, 1.137.

40 Chonghua refers to the mythical emperor Shun.

41 Ci refers to Duanmu Ci 端木賜 [Ca. 520-446 BCE], a disciple of Confucius known for his eloquence. He had a successful career as an official, which was rare among Confucius's disciples. 
base, therefore to be a male is considered honorable. Since I had the luck to become a male, this is my second joy. Among those who were born are some who do not see a day or a month or do not live beyond babyhood. Since I have lived for ninety years, this is my third joy. ${ }^{42}$

Rong was optimistic, and found value in such ordinary activities as playing musical instruments and singing. The Liezi's Confucius approved of his outlook on life. Tao then provides another example of an honorable poor scholar, Yuan Xian who was a disciple of Confucius and suffered from poverty but was unwilling to compromise his principles to acquire wealth. Through his austerity, Yuan adhered to Confucius' position on the relationship between poverty, wealth, and the Dao, articulated in the following passage from the Analects:

The Master said, "Wealth and high station are what men desire but unless I got them in the right way I would not remain in them. Poverty and low station are what men dislike, but even if I did not get them in the right way I would not try to escape from them."43

Confucius acknowledges the commonsense position that wealth and social status are desirable, but insists that obeying the Dao, the guiding principle in life, must come first. Furthermore, he emphasizes that the proper way to confront and even overcome poverty is through benevolence and virtues. Tao alludes not only to Yuan's commitment to this principle, but also to Yuan's conversation with Zigong, another of Confucius's disciples, regarding the difference between poverty [pin 貧] and distress [bing 病]. In that conversation, Yuan disputes Zigong's assessment of Yuan as “distressed," arguing:

I, Xian, have heard that if one lacks wealth, it is called poverty. If one studies the Dao yet is not able to put it into practice, it is called distress. As for me, Xian, I am impoverished but I am not distressed. ${ }^{44}$

42 Davis, T'ao Yüan - ming, 2.90.

43 Lau, Confucius: The Analects (New York: The Penguin Group, 1979), 72.

44 The translation is based on that of Alan Berkowitz, "Biographies of Recluses: Huangfu Mi's Accounts of High-Minded Men," in Early Medieval China: A Sourcebook, ed. Wendy Swartz et al. (New York: Columbia University Press, 2014), 342. 
In these allusions, Tao references two scholars whose physical poverty did not prevent them from enjoying meaningful and virtuous lives. Tao alludes to these figures not only to praise their values, but also to actively associate himself with them. For similar reasons, Tao dedicated a poem to Zhang Zhongwei 張仲蔚 of the Eastern Han [25-220]. The poem directly expresses Tao's deep appreciation of Zhang's personality and moral worth. Zhang's way of life was an example of the Dao in which Tao delighted:

\begin{tabular}{|c|c|}
\hline 其六 & $\mathrm{VI}^{45}$ \\
\hline 仲蔚愛窮居， & Zhongwei liked living a poor life. \\
\hline 蒿蓬。 & All around his residence grew wild grasses. \\
\hline 召交游， & Concealing himself, he broke away from social circuits. \\
\hline 頑能工。 & He was quite skilled at composing poetry. \\
\hline 舉世無知者, & In all the world, there was no one who knew him, \\
\hline & There was only Liu Gong. \\
\hline 月獨然? & Why was this scholar so lonely? \\
\hline 罕所同。 & $\begin{array}{l}\text { Indeed, because he could seldom find others } \\
\text { like himself. }\end{array}$ \\
\hline & He was steadfast and content with his deeds. ${ }^{46}$ \\
\hline & What he enjoyed was neither failure or success. \\
\hline & $\begin{array}{l}\text { Certainly, I am clumsy in dealing with the affairs } \\
\text { of men. }\end{array}$ \\
\hline & I just want to follow him for a long time. \\
\hline
\end{tabular}

Few historical records documenting Zhang Zhongwei survive, and his presence in Tao's yongshi shi is another element which distinguishes Tao's work from other poets in the genre, who focused on better-known figures. In his "Yong pinshi," Tao Yuanming often combines together references to several scholars, but this poem exclusively praises Zhang Zhongwei, demonstrating his profound admiration of Zhang. One of the few accounts of Zhang's life can be found in The Biographies of Lofty Figures [Gaoshizhuan 高士傳]:

45 Yuan, Tao Yuanming ji jianzhu, 375.

46 Xiaofei Tian points out that the alternate version of this line reads "Forsaking the roots, he pursued the branches" [Qi ben an qi mo 棄本案其末], and argues that this variant shows that Tao was posing an ironic challenge to the traditional understanding of moral improvement and political success. See Xiaofei Tian, Tao Yuanming \& Manuscript Culture: The Record of a Dusty Table (Seattle: University of Washington Press, 2005), 193-194. 
Zhang Zhongwei was a native of Pingling (northwest of modern Xianyang, Shaanxi). Together with Wei Jingqing of the same commandery, he cultivated the Dao and moral virtue. He lived as a recluse and did not hold an official position. He understood astronomy and natural science; he was skilled in prose composition and delighted in shi and fu poems. He lived simply and in constant poverty; where he lived wild grasses were overwhelming. He shut his gate and nourished his nature; he did not seek glory or fame. None of the men of his time recognized him; only Liu Gong knew him. ${ }^{47}$

Tao believed that because Zhang Zhongwei's happiness did not rely on conventional definitions of success and failure, a person like Zhang was close to the Dao. Zhang also offered a model for achieving one's goals even in an environment of scarcity. Zhang's example shows the influence on Tao of Confucian values - namely, the idea that righteousness, not worldly success or failure, is the path to spiritual affluence and satisfaction. If one does not follow this righteous path and instead pursues wealth and status for its own sake, it stains the conscience. In the Analects, Confucius compares these ill-gotten gains to a transitory cloud:

The Master said, "In the eating of coarse rice and the drinking of water, the using of one's elbow for a pillow, joy is to be found. Wealth and rank attained through immoral means have as much to do with me as passing clouds." ${ }^{48}$

As Confucius sees it, material possessions and status are transient, but the virtues of the Dao are permanent. Zhang Zhongwei's adherence to this model epitomizes Tao's belief of anpin ledao, to the point where Tao dedicates the entirety of a poem to him. Zhang's dedication to principle was not common among his contemporaries, so he had few friends or acquaintances [zhiyin 知音], but literature helped him to cope with poverty. ${ }^{49}$ Tao identified with Zhang Zhongwei so strongly that he chose to distance himself from his contemporaries and "communicate" with Zhang instead. Tao clearly demonstrates

47 The translation is based on Davis, T'ao Yüan - ming, 1.139.

48 Lau, Confucius: The Analects, 88.

49 Tao Yuanming believed that music could help people realize anpin ledao. For a discussion of Tao's understanding of the educational function of music, see Fan Ziye 范子燁, Youran wang Nanshan:Wenhua shiyu zhong de Tao Yuanming 悠然望南山一文化視域中的陶 淵明 (Shanghai: Dongfang chuban zhongxin, 2010), 40-45. 
this desire in the final couplet. James Hightower points out the function of the word zhuo 拙 in the penultimate line: "[Tao] is not pleading ineptitude as an excuse for staying out of worldly affairs, he is also claiming the kind of natural simplicity he spoke of in the first of the 'Back to the Farm' poems, 'Simplicity intact, I have come back to the field." ${ }^{50}$ For Tao, Zhang's reclusion and focus on self-cultivation represented an ideal model of simple virtue, and he paid particular attention to Zhang's close relationship with his few friends. Even more isolated than Zhang, Tao could only seek consolation and spiritual support in virtuous figures from antiquity.

Given that anpin ledao was neither a comfortable nor easy lifestyle to adopt, why was Tao drawn to it? Tao's embrace of the ideal is likely related to the fate of his own political pursuits in a complicated and tumultuous political environment. ${ }^{51}$ Tao had entered the service of Huan Xuan 桓玄 [369-404] in the second year of the Long'an 隆安 reign [397-401], when the latter was appointed as governor of Jiangzhou [Jiangzhou Cishi 江州刺史]. Tao served him for two years until his mother's death in the fourth year of the Long'an reign. In the spring of the third year of the Yuanxing 元興 reign [402-404], Tao returned to politics, serving Liu Yu 劉裕 [363-422], the future emperor of the Liu Song dynasty [420-479], as adjutant to the General in Command of Defense [Zhenjun canjun 鎮軍參軍]. In the third month of the first year of the Yixi 義熙 reign [405], Tao assumed the position of adjutant [Canjun 參軍] in Liu Jingxuan's 劉敬宣 [371-415] camp. In the eighth month of the same year, Tao became magistrate of Pengze County [Pengze ling 彭澤令], abandoning the position abruptly three months later, possibly due to his sister's death in Wuchang. The fast-changing and ruthless political environment Tao experienced over the course of his career likely influenced his decision to permanently become a recluse. Tao, who had worked with Liu Yu before Liu rebelled, may have sensed his ambition. Tao also witnessed the rise and fall of Huan Xuan, one of Liu's major competitors, whom Tao regarded highly. After experiencing so many disappointments, Tao's dream of achieving his ideals through politics began to fade. Reflecting on his life in his later years, Tao was keenly aware that he had not fulfilled the political aspirations expressed in the poetry he composed as a young man, and instead consoled himself by pointing

50 James Robert Hightower, The Poetry of T'ao Ch'ien (Oxford: Oxford University Press, 1970), 213 .

51 For a detailed analysis of the four major biographies of Tao Yuanming from the Six Dynasties, see Tian, Tao Yuanming \& Manuscript Culture, 67-94 and Wendy Swartz, Reading Tao Yuanming: Shifting Paradigms of Historical Reception (427-1900) (Cambridge: Harvard University Asia Center, 2008), 27-47. 
to his steadfast principles. As Wendy Swartz notes, the elegy of Tao written by Yan Yanzhi emphasized this moral quality: "All the descriptions of his life and character in the elegy point to the same pair of ideas: contentment in poverty and steadfastness in reclusion." ${ }^{25}$ Tao's sentiments were vindicated by later critics, most notably the influential late imperial literati Gui Youguang 歸有光 [1506-1571] and Wen Runeng 温汝能 [1748-1811], who praised his embrace of anpin ledao. ${ }^{53}$ Through his espousal of this ideal, Tao successfully secured his place in Chinese literary and cultural history.

Yet Tao's yongshi shi do not always focus on unsuccessful scholars. Tao also examines several historical figures who were able to achieve their goals. Tao advocates for those successful in achieving their goals to "withdraw after making contributions" [gongcheng shentui 功成身退]. The concept is to achieve something [gongcheng 功成], and then, as the wheel of fortune is always turning, especially in a chaotic era, to avoid potential disasters by withdrawing from politics [shentui 身退]. Gongcheng shentui comes from chapter two of the Dao de jing 道德經, which challenges the conventional wisdom around duality and contrasts, and explains the attitude a sage should hold toward achievements:

\begin{tabular}{|c|c|}
\hline 以聖人處無為之事, & $\begin{array}{l}\text { Therefore the sage keeps to the deed that } \\
\text { consists in taking no action }\end{array}$ \\
\hline 不不言之教。 & $\begin{array}{l}\text { and practices the teaching that uses } \\
\text { no words. }\end{array}$ \\
\hline 䓝物作焉而不辭（司）； & $\begin{array}{l}\text { The myriad creatures rise from it yet it claims } \\
\text { no authority; }\end{array}$ \\
\hline 有; & It gives them life yet claims no possession; \\
\hline & It benefits them yet exacts no gratitude; \\
\hline 成而弗居 & $\begin{array}{l}\text { It accomplishes its task yet lays claim to } \\
\text { no merit. }\end{array}$ \\
\hline & It is because it lays claim to no merit \\
\hline & That its merit never deserts it. ${ }^{54}$ \\
\hline
\end{tabular}

The sage follows nature and allows everything to proceed according to the Dao. The sage does not interfere with this process, nor claim ownership over it, but instead seeks to be remembered for his wise restraint in allowing the Dao to realize itself. By not deliberately seeking fame, the ethical person avoids

\footnotetext{
52 Swartz, Reading Tao Yuanming, 140.

53 Swartz, Reading Tao Yuanming, 128.

54 D.C. Lau, Tao Te Ching (Hong Kong: Chinese University of Hong Kong Press, 1989), 2.4-5.
} 
acting too intentionally and going against the Dao, and passes down their deeds and virtues. Chapter nine of the Dao de jing uses metaphors of water and a blade for the problems of wealth and fame, highlighting the importance of gongcheng shentui - knowing satisfaction and avoiding excesses which will keep one's achievement. ${ }^{55}$ In Tao's time, this idea provided a way to maintain one's principles, engage in public life, and yet still avoid the perils of political treachery and instability. Tao's poem on the two Shus explicitly delineates Tao's understanding of this idea:

$\begin{array}{ll}\text { 詠二疏 } & \text { Poem on the Two Shus }{ }^{56} \\ \text { 大象轉四時, } & \text { The Great Image turns the four seasons, } \\ \text { 功成者自去。 } & \text { Those who make contributions quietly take their leave. } \\ \text { 借問衰周來, } & \text { May I ask, since the decline of the Zhou, } \\ \text { 幾人得其趣? } & \text { How many people have followed this principle? } \\ \text { 游目漢廷中, } & \text { Roaming around the Han court, } \\ \text { 二疏復此舉。 } & \text { The two Shus revived this action. } \\ \text { 高嘯返舊居, } & \text { With a high whistle, they returned to their for- } \\ & \text { mer residence. } \\ \text { 長揖儲君傅。 } & \text { They paid their respect to the position of the } \\ & \text { Crown Prince's } \\ \text {....... } & \text { Tutor, bowing deeply.... } \\ \text { 誰云其人亡, } & \text { Who would say the two Shus passed away? } \\ \text { 久而道彌著! } & \text { The more time passes, the more prominent their } \\ & \text { Dao becomes. }\end{array}$

This poem is very similar, in both structure and content, to Zhang Xie's 張協 [d. ca. 307] poem on the topic of the Two Shus. ${ }^{57}$ Tao may have read both Zhang's poem and historical accounts and been moved by their adherence to gongcheng shentui. Indeed, Tao's second line is practically a restatement of this idea. Ziqu 自去 in that line refer to foregoing status and surrendering

55 Lau, Tao Te Ching, 12-13.

56 Yuan, Tao Yuanming jijianzhu, 379-380. The two Shus refer to Shu Guang 疏廣 [d. 45 BCE ] and Shu Shou 疏受 [d. 48 BCE], tutors of Emperor Xuan of Han 漢宣帝 [r. 74-48 BCE]. Their biography appears in Hanshu, 71.3040.

Zhang Xie's "Yongshi” can be found in Xiao Tong 蕭統 ed., Li Shan 李善, Lü Yanji 呂 延濟, Liu Liang 劉良, Zhang Xi 張銑, Lü Xiang 呂向 and Li Zhouhan 李周翰, annot., Liuchen zhu Wen xuan 六臣注文選 (Beijing: Zhonghua shuju, 1987), 39o. For a discussion of Zhang's "Yongshi" and other yongshi shi in the Wen xuan, see Yue Zhang, "Approaches to Lore in 'Poems on History' from the Selections of Refined Literature," Journal of Oriental Studies, 49.2 (2017): 83-112. 
influence - once political results are achieved, one should discard fame and reputation and withdraw from public life.

To explain gongcheng shentui, Tao raises the issue of dynastic transitions and then focuses on the two Shus, whom he considered to be the best representatives of how to approach that problem. Most of the poem celebrates the actions that result from their Daoist-influenced worldview: their abdication of official duties, and their indifference to fame and to leaving a material legacy for their descendants. Tao praises the two Shus for understanding the idea of gongcheng shentui and the true meaning of the Dao. After contributing to the state by tutoring the crown prince, they withdrew from politics and enjoyed a quiet life in their home village. They understood that trying to achieve more would have defied the will of nature and only undermined their aims. Their lack of interest in fame and material possessions made them influential models for generations of scholars and officials. The last couplet places the two Shus' deeds in a longer historical context, asserting that the Dao the two Shus adhered to will last forever. Where Tao's poem on the two Shus demonstrates the advantages of gongcheng shentui, his poem on the Three Good Men [Sanliang 三良] reveals what happens when historical figures exert and invest enormous effort in their political pursuits:

\begin{tabular}{|c|c|}
\hline 詠三良 & Poems on the Three Good Men \\
\hline 彈冠乘通津, & $\begin{array}{l}\text { "Dusting off our caps, we boarded the ferry, heading } \\
\text { in all directions. } 58\end{array}$ \\
\hline 但懼時我遺。 & We only feared that we missed our moment. \\
\hline 服勤盡歲月, & Working hard all year long, \\
\hline 常恐功愈微。 & $\begin{array}{l}\text { We often worried that our achievements were shrink- } \\
\text { ing by the day." }\end{array}$ \\
\hline$\ldots \ldots$ & $\ldots$ \\
\hline 一朝長逝後, & Once [their lord] passed away, \\
\hline 願言同此歸。 & They were willing to go with him. \\
\hline 厚恩固難忘, & Great kindness was indeed difficult to forget. \\
\hline 君命安可違?59 & How could they defy their lord's command? \\
\hline
\end{tabular}

The story of the Three Good Men can be found in many literary and historical accounts. Two representative historical accounts appear in the Zuozhuan 左傳 and the Shiji. The Zuozhuan is the earliest extant account:

\footnotetext{
$5^{8}$ The "ferry to all directions" [tongjin 通津] is a conventional trope for embarking on an official career.

59 Yuan, Tao Yuanming jijianzhu, 383.
} 
Renhao, the Duke of Qin died. With him were buried alive the three sons of the Ziju clan: Yanxi, Zonghang, and Qianhu. All three were among the finest men of the Qin. People of the state lamented over their fate and composed the poem "Yellow Bird."60

The account in the Shiji is similar:

In the thirty-ninth year [of his reign], Duke Mu died. He was interred at Yong. Those who followed him into death numbered one hundred seventy-seven. Among them were three members of the Ziyu family of good subjects, who were named Yanxi, Zhonghang, and Qianhu. The people of Qin mourned them and made and sang for them the poem "Huang niao."61

Both the Zuo zhuan and Shiji accounts record that after Lord Mu of Qin died, the Three Good Men were buried alive with him. The people of Qin lamented their fate and composed the poem "Yellow Birds" to commemorate them. Tao's poem demonstrates that the Three Good Men were eager to serve their country and diligently worked for their ruler. During their moment, they were highly favored, treated with dignity, and achieved great political success. However, their success was tightly bound to Lord $\mathrm{Mu}$, and they were therefore unable to withdraw from the political world before they met a grim fate. Gongcheng shentui requires the courage and willingness to abandon one's immediate interests, and the wisdom to leave the service of a ruler safely and smoothly. Practically speaking, such a withdrawal is often hard to achieve because a ruler is loath to relinquish a loyal and effective official. Gongcheng shentui profoundly influenced the course of Tao's life. It appears not only in his yongshi shi, but also in his poems addressed to family members. In his poem "Command to My Son" [Mingzi 命子], 62 Tao offers his forebears, and particularly his greatgrandfather Tao Kan 陶㑆 [259-334], to his son as models, depicting them as calm, resourceful, virtuous, and aloof from worldly fame:

6o The English translation is adopted, with some modification, from Ming Dong Gu, Chinese Theories of Reading and Writing: A Route to Hermeneutics and Open Poetics (Albany: State University of New York Press, 2005), 168.

61 Robert Joe Cutter, “On Reading Cao Zhi's ‘Three Good Men': Yong shi shi or Deng lin shi?” Chinese Literature: Essays, Articles, Reviews, 11 (1989): 1.

62 This poem was written for his eldest son, Tao Yan 陶儼, during the fourteenth year of the Taiyuan 太元 reign [376-396], when Tao Yan was three years old. See Yuan, Tao Yuanming jijianzhu, 44. Between 386 and 397, Tao Yuanming resided at home, and several of his sons were born during this period: his second son Si 俟 was born in 388, his third son Fen 份 and fourth son Yi 佚 were born in 389, and his youngest child Tong 佟 was born in 394. See Yuan, Tao Yuanming ji jianzhu, 845-867. 


$\begin{array}{ll}\text { 桓桓長沙, } & \text { How mighty and powerful Changsha was, } \\ \text { 伊勳伊德。63 } & \text { His great deeds and his virtues! } \\ \text { 天子疇我, } & \text { The emperor rewarded him with farmland. } \\ \text { 專征南國。 } & \text { He commanded a punitive expedition against the south. } \\ \text { 功遂辭歸, } & \begin{array}{l}\text { After his accomplishments, he withdrew from politics } \\ \text { and returned home. }\end{array} \\ \text { 臨寵不忒。 } & \text { Receiving favor, he did not stray. } \\ \text { 孰謂斯心, } & \text { Who would say that this spirit } \\ \text { 而近可得。64 } & \text { Can be found in recent times? }\end{array}$

Tao's great-grandfather Tao Kan helped found the Eastern Jin dynasty [317420] and held such high-ranking positions as grand marshal [da sima 大司馬]. But after reaching this level of success, he retreated from political life, refusing even the important positions bestowed upon him personally by the emperor. Tao Yuanming therefore saw gongcheng shentui as part of his family legacy, a legacy he wanted his sons to continue.

This article investigates Tao's perspective on life as expressed in his yongshi shi. Tao was well-read, and his rich understanding of Chinese culture is deeply rooted in that reading, but his perspective on life is also a product of his own life experience. The historical figures that Tao commented on are distributed across many centuries, from Ji and Xie in the mythical reigns of Yao 堯 and Shun 舜 to several figures from the Eastern Han. For the most part, the subjects of these poems were not majestic rulers nor major officials, but virtuous and upright scholars whom Tao saw as men worthy of emulation. By analyzing Tao's interpretation of the legacies of these scholars, we can better understand his perspective on life and his personality, which in turn augments our ability to interpret his other writings.

Tao's yongshi shi emphasize a series of key values and concepts he felt were key to leading a successful, ethical life. Tao believed that timeliness was essential to the political success of the scholar. Ji and Xie became virtuous models of great officials because they arrived at the right historical moment, whereas the equally virtuous Qu Yuan and Jia Yi were suspected and slandered because they arrived on the political stage at the wrong time. Tao felt that without timeliness, regardless of one's efforts and dedication, it would be nearly impossible to achieve lasting political accomplishments, and he therefore encouraged literati not to try to manufacture opportunities through clever schemes and artful

\footnotetext{
63 Tao Kan's posthumous title was Huan 桓, which when reduplicated means "mighty and powerful." He was granted the title Commandery Duke of Changsha [Changshajungong 长沙郡公] in recognition of his military merits.

Yuan, Tao Yuanming ji jianzhu, 41 .
} 
rhetoric. Such tactics would be not only unseemly but ultimately counterproductive, as was tragically the case for Han Fei. Tao sometimes contradicted the verdicts of the historical accounts he alluded to and re-evaluated these figures according to his own ideals, as in the case of the two Confucian scholars and Shusun Tong described in the Shiji. Tao sought to use literature to circulate accounts of "unappreciated scholars" and in doing so, make a space for them in literary history. Writing yongshi shi was a way to achieve many aspirations: expressing emotions, making up for political failure, transmitting one's ideas and intentions to later readers, and achieving literary immortality.

Along with advocating for the achievement of one's goals by means of literature, Tao was committed to the ideal of anpin ledao. Adhering to the Dao was not an abstract concept in Tao's poems, but was rather made concrete through the example of praiseworthy ancient figures, and lived cultural practices such as reading, writing, and making and appreciating music. Living in poverty was difficult, but the historical figures that Tao praised overcame these difficulties and were able to uphold the principles of the Dao. Like Tao, most of these historical figures lived through transitional and chaotic periods and consequently withdrew from politics, abandoned efforts to pursue fame and reputation, and focused instead on cultivating their moral values. Tao projected himself onto these historical figures, and his vivid depictions of professed moral values in turn influenced later readers understanding of Tao's personality and output.

Although some of Tao's yongshi shi discuss life on the farm, for Tao, farming was a channel for putting his ideals into practice, and his focus remained on cultivating virtue. By commemorating historical figures in poems, Tao kept these figures alive in the spiritual world and the imaginary of scholars long after they would have otherwise been forgotten. Tao's yongshi shi have served as a medium for passing down the deeds and virtues of historical figures to future generations. Tao connected ancient figures with a future audience and in doing so, he placed himself in this lineage. ${ }^{65}$ In writing yongshi shi, Tao expressed his profound understanding of the past. He not only presented examples of literati dealing with unfavorable political situations, cherishing the Dao in adversity, and withdrawing from office after achievements were made, but also incorporated his own experience of internalizing these principles, making them more concrete and personal.

65 Tao's self-idealization through linking himself with virtuous historical figures is similar to that of Zuo Si 左思 [ca. 250-ca. 305], a major poet known for writing yongshi shi. For recent studies on Zuo and his yongshi shi, see Yue Zhang, "Self-Canonization in Zuo Si's Poems on History," Journal of Chinese Humanities, 5 (2020): 215-244, and Yue Zhang, "The Reception of Zuo Si's 'Poems on History' in Early Medieval China," Frontiers of Literary Studies in China, 14.1 (2020): 48-75. 


\section{Works Cited}

Ashmore, Robert. The Transport of Reading: Text and Understanding in the World of Tao Qian (365-427). Cambridge: Harvard University Asia Center, 2010.

Ban $\mathrm{Gu}$ 班固. Hanshu 漢書 [The History of the Han Dynasty]. Beijing: Zhonghua shuju, 1962.

Berkowitz, Allan J. Patterns of Disengagement: The Practice and Portrayal of Reclusion in Early Medieval China. Stanford: Stanford University Press, 2000.

Chai, David, ed. Dao Companion to Xuanxue 玄學 (Neo-Daoism). Dordrecht: Springer, 2020.

Cutter, Robert Joe. “On Reading Cao Zhi's ‘Three Good Men': Yong shi shi or Deng lin shi?" Chinese Literature: Essays, Articles, Reviews, 11 (1989): 1-11.

Davis, A.R. T'ao Yüan - ming (AD 365-427): His Works and Their Meaning, 2 vols. Cambridge: Cambridge University Press, 2009.

Fan Ziye 范子燁. Youran wang Nanshan - Wenhua shiyu zhong de Tao Yuanming 悠然望 南山一文化視域中的陶淵明 [Gazing on South Mountain Leisurely - Tao Yuanming in the Cultural Horizon]. Shanghai: Dongfang chuban zhongxin, 2010.

Gu Ming Dong. Chinese Theories of Reading and Writing: A Route to Hermeneutics and Open Poetics. Albany: State University of New York Press, 2005.

Hightower, James Robert. The Poetry of T'ao Ch'ien. Oxford: Oxford University Press, 1970.

Lau, D.C. Confucius: The Analects. New York: The Penguin Group, 1979.

Lau, D.C. Tao Te Ching. Hong Kong: Chinese University of Hong Kong, 1989.

Li Yaonan 李耀南. "Xuanxue shiye zhong de Tao Yuanming rensheng guan he shenmei rensheng jingjie 玄學視野中的陶淵明人生觀和審美人生境界.” Huazhong keji daxue xuebao 華中科技大學學報 16, no. 6 (2002): 23-28.

Luo Zongqiang 羅宗強. Xuanxue yu Wei Jin shiren xintai 玄學與魏晉士人心態. Hangzhou: Zhejiang renmin chubanshe, 1991.

Qi Yishou 齊益壽. Huangju dongli yao gujin: Tao Yuanming qiren qishi sanlun 黃菊 東篗耀古今: 陶淵明其人其詩散論 [Yellow Chrysanthemum and Eastern Hedges Illuminate the Present and the Past: Assorted Thoughts on Tao Yuanming and His Poetry]. Taipei: Guoli Taiwan daxue chubanshe, 2016.

Shen Yue 沈約. Songshu 宋書 [The History of the Song Dynasty]. Beijing: Zhonghua shuju, 1974 .

Sima Qian 司馬遷. Shiji 史記 [Records of the Grand Historian]. Beijing: Zhonghua Shuju, 1959.

Swartz, Wendy. Reading Tao Yuanming: Shifting Paradigms of Historical Reception (4271900). Cambridge: Harvard University Asia Center, 2008.

Swartz, Wendy, Robert Ford Campany, Yang Lu, and Jessey J. C. Choo, eds. Early Medieval China: A Sourcebook. New York: Columbia University Press, 2014. 
Tao Xinmin 陶新民. “Tao Yuanming: Xuanxue rensheng guan de zhongjie yu xuanyan shi de chaoyue 陶淵明: 玄學人生觀的終結與玄言詩的超越. Anhui daxue xuebao 安徽大學學報 24, no.1 (2000): 40-46.

Wang Xianqian 王先謙.Zhuangzijijie 莊子集解 [Collected Interpretations on Zhuangzi]. Beijing: Zhonghua shuju, 1987.

Watson, Burton, trans. Han Fei Tzu: Basic Writings. New York: Columbia University Press, 1964 .

Watson, Burton. The Complete Works of Zhuangzi. New York: Columbia University Press, 2013.

Tian Xiaofei. Tao Yuanming \& Manuscript Culture: The Record of a Dusty Table. Seattle: University of Washington Press, 2005.

Wei Chunxi 韋春喜. Song qian yongshi shi shi 宋前詠史詩史 [History of Poems on History prior to the Song]. Beijing: Zhongguo shehui kexue chubanshe, 2010.

Xiao Tong 蕭統, ed., Li Shan 李善, Lü Yanji 呂延濟, Liu Liang 劉良, Zhang Xi 張銑, Lü Xiang 呂向 and Li Zhouhan 李周翰, annot. Liuchen zhu Wen xuan 六臣注文選 [Six Ministers' Annotation of Selections of Refined Literature]. Beijing: Zhonghua shuju, 1987.

Yuan Xingpei 袁行䨌. Tao Yuanming ji jianzhu 陶淵明集箋注 [Annotation of and Commentary on Tao Yuanming's Oeuvre]. Beijing: Zhonghua shuju, 2003.

Zhang Yue. "A Selective Bibliography of Mainland Chinese Books (2002-2010) on Early Medieval Chinese Literature (220-589)." Early Medieval China 18 (2012): 69-86.

Zhang Yue. "Approaches to Lore in 'Poems on History' from the Selections of Refined Literature." Journal of Oriental Studies, 49.2 (2017): 83-112.

Zhang Yue. “Ou Mei jinqi Tao Yuanming yanjiu zongshu fenxi yu zhanwang 歐美近期 陶淵明研究綜述、分析與展望 [Summary and Analysis of Recent Studies on Tao Yuanming in Europe and America]." Gudian wenxian yanjiu 古典文獻研究 20.2 (2017): 289-304.

Zhang Yue. "Self-Canonization in Zuo Si's Poems on History." Journal of Chinese Humanities, 5 (2020): 215-244.

Zhang Yue. "The Reception of Zuo Si's 'Poems on History' in Early Medieval China.” Frontiers of Literary Studies in China, 14.1 (2020): 48-75.

Zhang Yue. "A Selective Bibliography of Mainland Chinese Books (2010-2019) on Early Medieval Chinese Literature." Early Medieval China 26 (2020): 88-109.

Zhong Shulin 鍾書林. Yinshi de shendu: Tao Yuanming xintan 隱士的深度: 陶淵明新探 [The Depth of a Recluse: A New Investigation of Tao Yuanming]. Beijing: Zhongguo shehui kexue chubanshe, 2015 . 